\section{Narcissus Cultivar Differences in Response to Saline Irrigation When Application Began Either Pre- or Postemergence}

\author{
Maren E. Veatch-Blohm ${ }^{1}$, Dorothy Chen, and Matthew Hassett \\ Biology Department, Loyola University Maryland, 4501 N. Charles Street, \\ Baltimore, MD 21210
}

Additional index words. daffodil, 'Dutch Master', 'Tete-a-Tete', 'Ice Follies', 'Actaea', ion distribution, salt stress

\begin{abstract}
Salinity affects crop production worldwide and can be particularly problematic for ornamental plants. Daffodils (Narcissus sp. L.) are one of the most popular bulb plants, in demand for both landscapes and cut flowers. In this study we examined how moderate salinity, imposed as $\mathrm{NaCl}$, affected growth, flower production, and leaf physiology when salinity treatment began either pre- or postemergence. Salinity did not affect growth rate or flower production for the three early-season cultivars ('Dutch Master', 'Ice Follies', and 'Tete-a-Tete') regardless of when salinity treatment began, but there were reductions in dry shoot biomass production under the highest salinity $(50 \mathrm{~mm}$ $\mathrm{NaCl}$ ). The mid-/late-season cultivar ('Actaea') had growth reduction and decreased flower production at the highest salinity when salinity treatment began preemergence. Within 28 days of greenhouse growth, the plants in the $50 \mathrm{~mm} \mathrm{NaCl}$ treatment had carbon assimilation rates of only $25 \%$ to $32 \%$ of the $0 \mathrm{~mm} \mathrm{NaCl}$ control. Sodium concentration increased $35 \%$ to $900 \%$ in the leaves in response to salinity for all cultivars when salinity treatment began preemergence but significantly increased only for 'Actaea' and 'Tetea-Tete' $(42 \%$ to $235 \%)$ when salinity treatment began postemergence. Potassium concentration in the shoot was mostly stable in response to salinity. The ability to maintain potassium (K) content within the plant may help daffodils tolerate the negative effects of sodium (Na). We believe that 'Actaea' was more negatively affected by salinity than the other three cultivars because, as a mid-/late-season cultivar, it had a much longer exposure period to salinity than the three early-season cultivars. However, moderate salinity does not seem to have a significant impact on growth and visual quality for 'Dutch Master', 'Ice Follies', or 'Tete-a-Tete' indicating that at least some saline water can be used for plant production without losses in plant quality.
\end{abstract}

Salinity is a major problem affecting up to one-third or more of agricultural land worldwide with the affected amount expected to increase (Carter et al., 2005; Cassaniti et al., 2009; Munns and Tester, 2008; Shibli et al., 2007). In addition to arid and semiarid areas, salinity is a problem in urban areas where high-quality water is being used for human consumption such that agricultural and horticultural production may have to rely on brackish, saline, or reclaimed irrigation water that have electrical conductivities (ECs) greater than that for optimal production (Arabiyat, 2005; Kirzhner et al., 2008; Marcum, 2006; Safi et al., 2007; Shillo et al., 2002). In addition to being scarce, high-quality water for plant production may also be costprohibitive (Arabiyat, 2005; Carter et al., 2005; Kirzhner et al., 2008; Marcum, 2006; Shillo et al., 2002).

Salinity, especially that imposed by $\mathrm{NaCl}$, results in reductions to plant growth and

Received for publication 18 Dec. 2012. Accepted for publication 23 Jan. 2013.

${ }^{1}$ To whom reprint requests should be addressed; e-mailmblohm@loyola.edu. and are often forced to provide flowers during the winter months (Anderson and van der Hoeven, 1998; Cantor and Gheorghita, 2011). Daffodils are an important bulb crop in the United Kingdom, The Netherlands, Israel, and the United States (Benschop et al., 2010; Carder and Grant, 2002; ERS, 1995; Hanks, 2002) accounting for $42 \%$ of bulb sales in the United Kingdom in 2011 (MAFF, 2012). 'Tete-a-Tete' is the most popular cultivar [e.g., in The Netherlands over one-third of all daffodil acreage is planted to 'Tete-aTete' (Benschop et al., 2010)], with 'Dutch Master', and 'Ice Follies' also ranked consistently in the top five (Hanks, 2002).

Research on daffodils has examined how daffodils affect the growth or vase life of other flowers (Van Doorn, 1998; Van Doorn et al., 2004), factors affecting daffodil flower senescence and bulb disease control, and best practices for commercial production (Carder and Grant, 2002; Hanks, 2002; Hunter et al., 2002, 2004; Jones and Hill, 1993; Krug et al., 2006), but there is currently no research on how salinity affects daffodil growth. Daffodils come up early in the spring, next to roads or walkways that have been treated in the winter with deicing salts (mainly applied as $\mathrm{NaCl}$ ), that are known to have adverse effects on other landscape plants, either directly or by affecting soil structure and soil nutrition (Berkheimer and Hanson, 2006; Cunningham et al., 2008; Green et al., 2008). Thus, we were interested in how moderate salinity (imposed as $\mathrm{NaCl}$ ) would affect growth, flower production, and leaf physiology of daffodils from four different daffodil divisions (I, II, IX, XII).

\section{Materials and Methods}

Daffodil cultivars. There are 13 divisions of daffodil cultivars and we used daffodils from four of these divisions: Division I (Trumpet Daffodils) with a cup at least as long as the petals, Division II (Large Cupped Daffodils) with the cup being greater than one-third of the length of the petals but not as long as the petals, Division IX (Poeticus Daffodils) with a small cup and white petals, and Division XII (Miscellaneous Daffodils) that do not fit into the other divisions (Daffodil.org, 1995-2011). The four following cultivars were used throughout the study: Division I 'Dutch Master' (Narcissus sp.), Division II 'Ice Follies' (Narcissus sp.), Division IX 'Actaea' ( $N$. poeticus L.), and Division XII 'Tete-a-Tete' (Narcissus sp.).

Growth conditions. The bulbs were planted in October each year $(2009,2010,2011)$ with the tip of the bulb at the soil line in 8-inch pots $\left(2940.7 \mathrm{~cm}^{3}\right)$ in Sunshine Potting Mix \#1. The potted bulbs were then placed in a cold room at $4{ }^{\circ} \mathrm{C}$ for 14 weeks starting in October (Cantor and Gheorghita, 2011). The plants were irrigated by hand every 21 to $28 \mathrm{~d}$ during the cold induction period. All treatment solutions contained Peter's 20-20-20 fertilizer. The bulbs that were to be subjected to salinity postemergence were irrigated with a $0 \mathrm{~mm}$ $\mathrm{NaCl}$ solution. When the bulbs were being 
tested for their response to salinity when $\mathrm{NaCl}$ exposure began preemergence, all of the salinity treatments were originally

Table 1. Electrical conductivity (EC) $\left(\mathrm{dS} \cdot \mathrm{m}^{-1}\right)$ of irrigation solution and soil effluent at the end of the treatment period when moderate salinity treatment $(0,25$, and $50 \mathrm{~mm} \mathrm{NaCl})$ began either pre- or postemergence $(n=3)$.

\begin{tabular}{|c|c|c|}
\hline \multirow{2}{*}{$\begin{array}{l}\text { Treatment } \\
(\mathrm{mm} \mathrm{NaCl})\end{array}$} & \multicolumn{2}{|c|}{$\mathrm{EC}\left(\mathrm{dS} \cdot \mathrm{m}^{-1}\right)$} \\
\hline & Irrigation solution & Soil effluent \\
\hline & \multicolumn{2}{|c|}{ Preemergence } \\
\hline 0 & 0.85 & 3.65 \\
\hline 25 & 3.33 & 10.50 \\
\hline 50 & 6.31 & 14.66 \\
\hline & \multicolumn{2}{|c|}{ Postemergence } \\
\hline 0 & 0.85 & 1.98 \\
\hline 25 & 3.33 & 5.80 \\
\hline 50 & 6.31 & 12.22 \\
\hline
\end{tabular}

irrigated with the lowest salinity treatment that was not the control solution. At each subsequent irrigation, the plants were exposed to a higher salinity until their target salinity was reached (see Table 1).

After 14 weeks of cold exposure, the pots were placed in a greenhouse in a randomized complete block with four blocks when salinity treatment began preemergence and five blocks when salinity treatment began postemergence. The plants were irrigated with $300 \mathrm{~mL}$ of their appropriate solution approximately twice a week, which kept the soil moist during active growth (The American Daffodil Society, 2006). The average leaching fraction was $15 \%$ to $25 \%$. All irrigation solutions contained Peter's 20-20-20 fertilizer supplying nitrogen at a rate of $120 \mathrm{mg} \cdot \mathrm{kg}^{-1}$. The average EC of each treatment and the average EC of the soil effluent at the end of treatment are in Table 1. The average high and low temperatures \pm SD in the greenhouse were as follows: $22.03 \pm 5.50$ and $16.31 \pm 5.50{ }^{\circ} \mathrm{C}$ for $2010,23.84 \pm 5.61$ and $16.83 \pm 3.67^{\circ} \mathrm{C}$ for 2011 , and $25.76 \pm 5.87$ and $18.58 \pm 4.43^{\circ} \mathrm{C}$ for 2012. The plants were grown in the greenhouse for 5 weeks before harvest by which time the majority of plants (except 'Actaea') had already bloomed and experienced flower senescence.

Plant evaluation when salinity treatment began preemergence. As a result of space limitations in 2010 and 2011, this experiment was conducted only on 'Dutch Master' and 'Tete-a-Tete'. In 2012, we ran the same experiment with 'Ice Follies' and 'Actaea'. Initial bulb weights \pm SE were as follows: 'Dutch Master' $47.83 \pm 1.96$ g, 'Ice Follies'
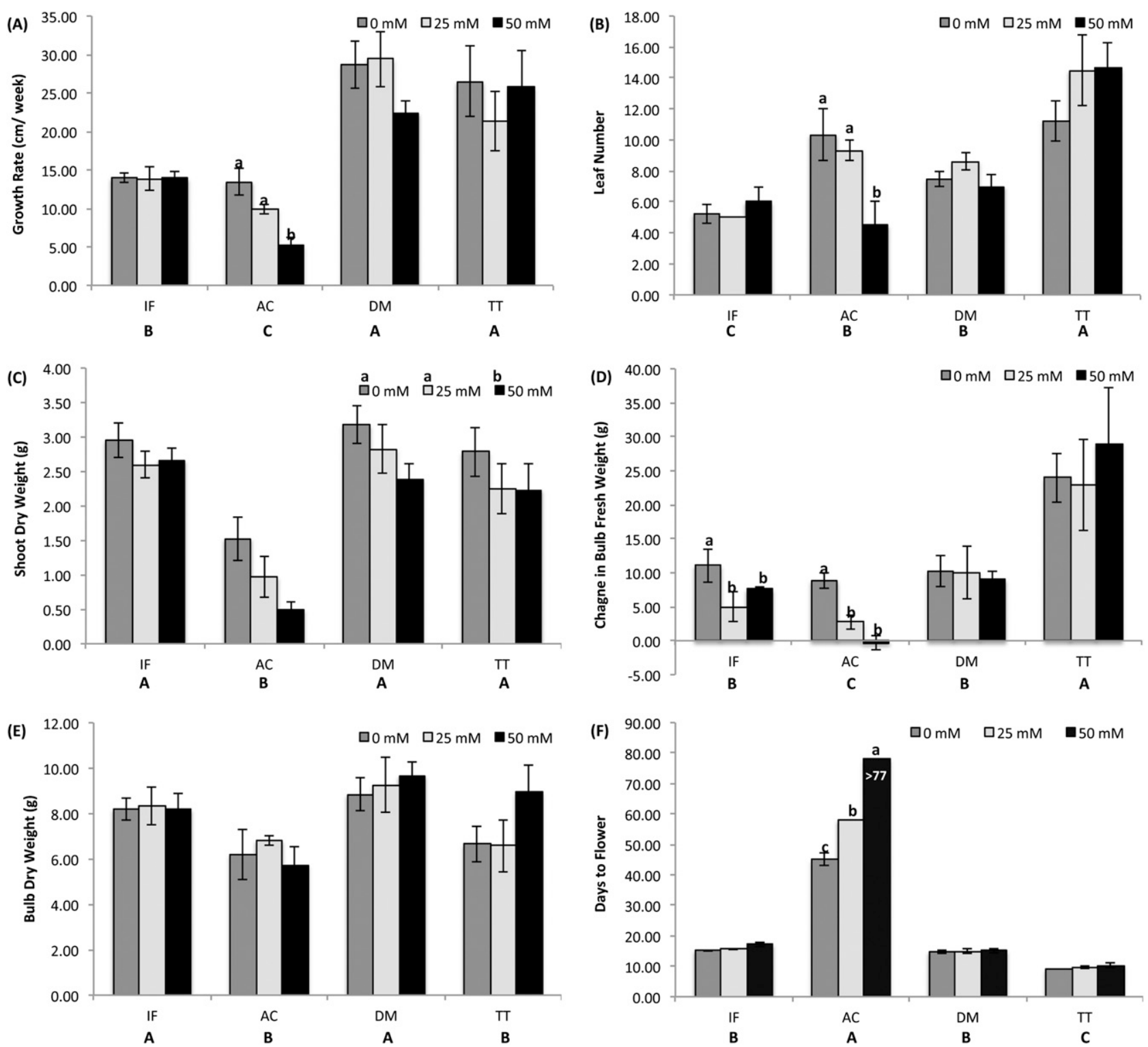

Fig. 1. Mean $\pm \mathrm{SE}(\mathbf{A})$ shoot growth rate, (B) leaf number at harvest, $(\mathbf{C})$ shoot dry weight, (D) bulb change in fresh weight, (E) bulb dry weight, and (F) days to flower of four daffodil cultivars exposed to saline irrigation $(0,25$, or $50 \mathrm{~mm} \mathrm{NaCl})$ for $98 \mathrm{~d}$ preemergence and $35 \mathrm{~d}$ postemergence. Cultivar abbreviations are as follows: 'Ice Follies' (IF), 'Actaea' (AC), 'Dutch Master' (DM), and 'Tete-a-Tete' (TT). Cultivars with the same capital letter are not significantly different according to Tukey's honestly significant difference (HSD) $(P<0.05)$ and salinity treatments with the same lower case letter are not significantly different according to Tukey's HSD $(P<0.05)$. Data are means of two runs of four replications for 'Dutch Master' and 'Tete-a-Tete' $(\mathrm{n}=8)$ and one run of four replications for 'Ice Follies' and 'Actaea' $(\mathrm{n}=4)$. 
$36.92 \pm 1.26 \mathrm{~g}$, 'Actaea' $27.32 \pm 1.49 \mathrm{~g}$, and 'Tete-a-Tete' $27.79 \pm 1.85 \mathrm{~g}$. The growth of the plants was evaluated every $7 \mathrm{~d}$ for $35 \mathrm{~d}$, once the plants were transferred to the greenhouse, by measuring the height of each stem and adding all of the heights together. As a result of the prolonged time required for 'Actaea' to flower, it was measured for $77 \mathrm{~d}$. Flower number per plant and the number of days it took for each plant to flower were also recorded. During 2011, photosynthetic rate (A), stomatal conductance $\left(g_{\mathrm{S}}\right)$, and transpiration rate $(\mathrm{E})$ were measured at solar noon twice during the treatment period. Measurements were collected using an LCi Portable Photosynthesis System (ADC Bioscientific Ltd., Great Amwell, U.K.) using ambient conditions on sunny days on fully expanded leaves that were not shaded by other leaves on the plant. At harvest, the number of leaves and the fresh weight and dry weight of the stems and bulbs were recorded. The bulbs were thoroughly rinsed to remove excess soil before being placed in a drying oven at $80^{\circ} \mathrm{C}$ for $72 \mathrm{~h}$ until a constant weight was reached.

At harvest a sample was taken from the upper third of a leaf for estimation of relative water content (RWC) as described by Bogeat-Triboulot et al. (2007). Another sample from the upper third of a leaf was taken at harvest and immediately frozen for analysis of leaf osmotic potential $\left(\psi_{\mathrm{S}}\right)$. Leaf $\psi_{\mathrm{S}}$ was determined using a Wescor Vapro 5220 Vapor Pressure Osmometer (Wescor Inc., Logan, UT). A mix of dried samples was taken from both the bulbs and leaves and prepared for atomic absorption spectrometry through $\mathrm{HNO}_{3}$ digestion as described in Grusak (1994) and Pomper and Grusak (2004). The samples were analyzed for $\mathrm{Ca}^{2+}, \mathrm{Mg}^{2+}, \mathrm{K}^{+}$, and $\mathrm{Na}^{+}$content using flame atomic absorption spectrometry (Olsen and Ulicny, 2001).

Plant evaluation when salinity treatment began postemergence. Initial bulb weights \pm SE were as follows: 'Dutch Master' $51.59 \pm$ $1.54 \mathrm{~g}$, 'Ice Follies' $40.35 \pm 1.21 \mathrm{~g}$, 'Actaea' $39.13 \pm 1.47 \mathrm{~g}$, and 'Tete-a-Tete' $31.08 \pm 0.90 \mathrm{~g}$. In 2010 and 2011, all plants not assigned to the $0 \mathrm{~mm} \mathrm{NaCl}$ control were exposed to either the 25 or $50 \mathrm{~mm} \mathrm{NaCl}$ treatments only after the plants were placed in the greenhouse. Shoot growth and flower production were measured every $7 \mathrm{~d}$ as stated previously for the preemergence experiments, and the plants were harvested after $35 \mathrm{~d}$ of treatment. Although the number of days it took for the plants to flower was not recorded, we did record the week that plants flowered. Photosynthesis, $g_{\mathrm{S}}$, and E were measured three times throughout the experiment, in 2011, starting at $14 \mathrm{~d}$ of $\mathrm{NaCl}$ treatment. All other measurements (RWC, $\psi_{\mathrm{S}}$, and ion analysis) were done as described previously.

Statistical analysis. All data were analyzed using the general linear model in the Fit Model platform of JMP8 (SAS Institute Inc., 1998-2008). Initial bulb weight was a covariate for all analyses. Each model included the following explanatory variables: block, salinity, cultivar, and salinity $\times$ cultivar. When the data analysis combined data from more than one run of the experiment, run was also included as an explanatory variable. The following data were transformed to meet the assumptions of normality. All of the growth and nutrient data were natural log-transformed. Specific comparisons among groups were conducted using Tukey's honestly significant difference. A $P$ value $<0.05$ was considered significant throughout.

\section{Results}

Plant growth, carbon assimilation, and plant ion status when moderate salinity treatment began preemergence. Growth rate did not differ significantly among salinities, but did vary significantly among cultivars (Fig. 1A). The one exception was 'Actaea', which had reduced growth in the $50 \mathrm{~mm}$ $\mathrm{NaCl}$ treatment (Fig. 1A). At harvest, when leaf number was recorded, there was a significant salinity $\times$ cultivar interaction with 'Actaea' producing significantly fewer leaves in the $50 \mathrm{~mm} \mathrm{NaCl}$ treatment compared with the other two treatments (Fig. 1B). Leaf production was unaffected by salinity in any of the other three cultivars (Fig. 1B). Shoot fresh weight and dry weight were significantly correlated $\left(R^{2}=0.92, P<0.0001\right)$; therefore, only the dry weight data will be presented. Dry weight was significantly reduced in the $50 \mathrm{~mm}$ $\mathrm{NaCl}$ treatment compared with the control with no significant interaction between salinity and cultivar (Fig. 1C). There were significant differences in bulb fresh weight (final-initial) in 'Ice Follies' and 'Actaea' with plants in both salinity treatments showing less of a change than the control (Fig. 1D). On the other hand, bulb dry weight did not vary among salinity treatments (Figs. 1E). The shoot to bulb ratio was significantly reduced in the $50 \mathrm{~mm} \mathrm{NaCl}$ treatment compared with the control with an $8 \%$ to $60 \%$ reduction depending on cultivar (Table 2).

Table 2. Ratios of shoot to bulb biomass, shoot and bulb $\mathrm{K}^{+}$and $\mathrm{Na}^{+}$content $(\% \mathrm{DW})$, and $\mathrm{K}^{+}: \mathrm{Na}^{+}$ratio in four daffodil cultivars exposed to saline irrigation $(0,25$, or $50 \mathrm{~mm} \mathrm{NaCl})$ for $98 \mathrm{~d}$ preemergence and $35 \mathrm{~d}$ postemergence ( $77 \mathrm{~d}$ for 'Actaea'). ${ }^{\mathrm{z}}$

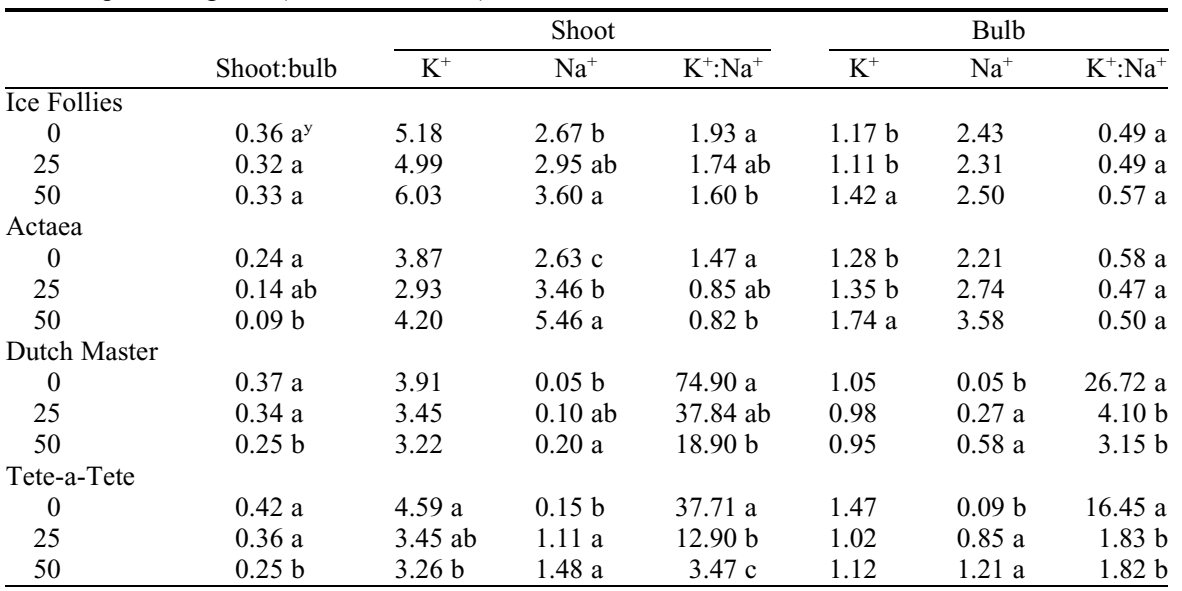

${ }^{2}$ Data are means of two runs of four replications for 'Dutch Master' and 'Tete-a-Tete' $(n=8)$ and one run of four replications for 'Ice Follies' and 'Actaea' $(n=4)$.

${ }^{y}$ Values within the same column within the same cultivar with the same letter were not significantly different according to Tukey's honestly significant difference at $P \leq 0.05$.

DW $=$ dry weight.
The number of flowers produced per plant that flowered was not significantly affected by salinity; however, it did vary significantly among cultivars. The average number of flowers per cultivar \pm SE was for 'Tete-a-Tete' $4.67 \pm 0.85$, for 'Dutch Master' $1.29 \pm 0.24$ $1.00 \pm 0.00$. Flowering time differed signifi cantly among cultivars but not among salinities for the following cultivars: 'Tete-a-Tete' flowered most quickly followed by 'Dutch Master' and 'Ice Follies' (Fig. 1F). Salinity significantly affected flowering time and flowering success in 'Actaea' only. Plants in the Nel treatment took an average of 45 flower in the $25 \mathrm{~mm} \mathrm{NaCl}$ treatment took $58 \mathrm{~d}$ to flower, and after $77 \mathrm{~d}$, no plants in the $50 \mathrm{~mm} \mathrm{NaCl}$ treatment had flowered or had formed flower buds (Fig. 1F).

Carbon assimilation, $g_{\mathrm{S}}$, and $\mathrm{E}$ were only measured in 2011. The measurements were which corresponded to 112 and 133 of $\mathrm{NaCl}$ exposure, respectively. On Day 112 , the photosynthetically active radiation $(P A R)$ was on average $410 \mu \mathrm{mol} \cdot \mathrm{m}^{-2} \cdot \mathrm{s}^{-1}$, and there was no significant effect of salinity on carbon assimilation rate (Fig. 2A); unfortunately, there was not sufficient data for $\mathrm{E}$ and $g_{\mathrm{s}}$ recorded for Day 112 to statistically analyze. By Day 133 (average $P A R$ of $455 \mu \mathrm{mol} \cdot \mathrm{m}^{-2} \cdot \mathrm{s}^{-1}$ ), the carbon assimilation rate in both the 25 and than $75 \%$ compared with the control, which had increased significantly compared with the Stomatal conductance was also significantly transpiration rate was only significantly reduced in the $50 \mathrm{~mm} \mathrm{NaCl}$ treatment (Fig. 2B-C). Leaf RWC did not differ among salinity treatments or cultivars with an average RWC of $69 \% \pm 3 \%$. Leaf $\psi_{\mathrm{S}}$ was also not initial measurement on Day 112 (Fig. 2A). 

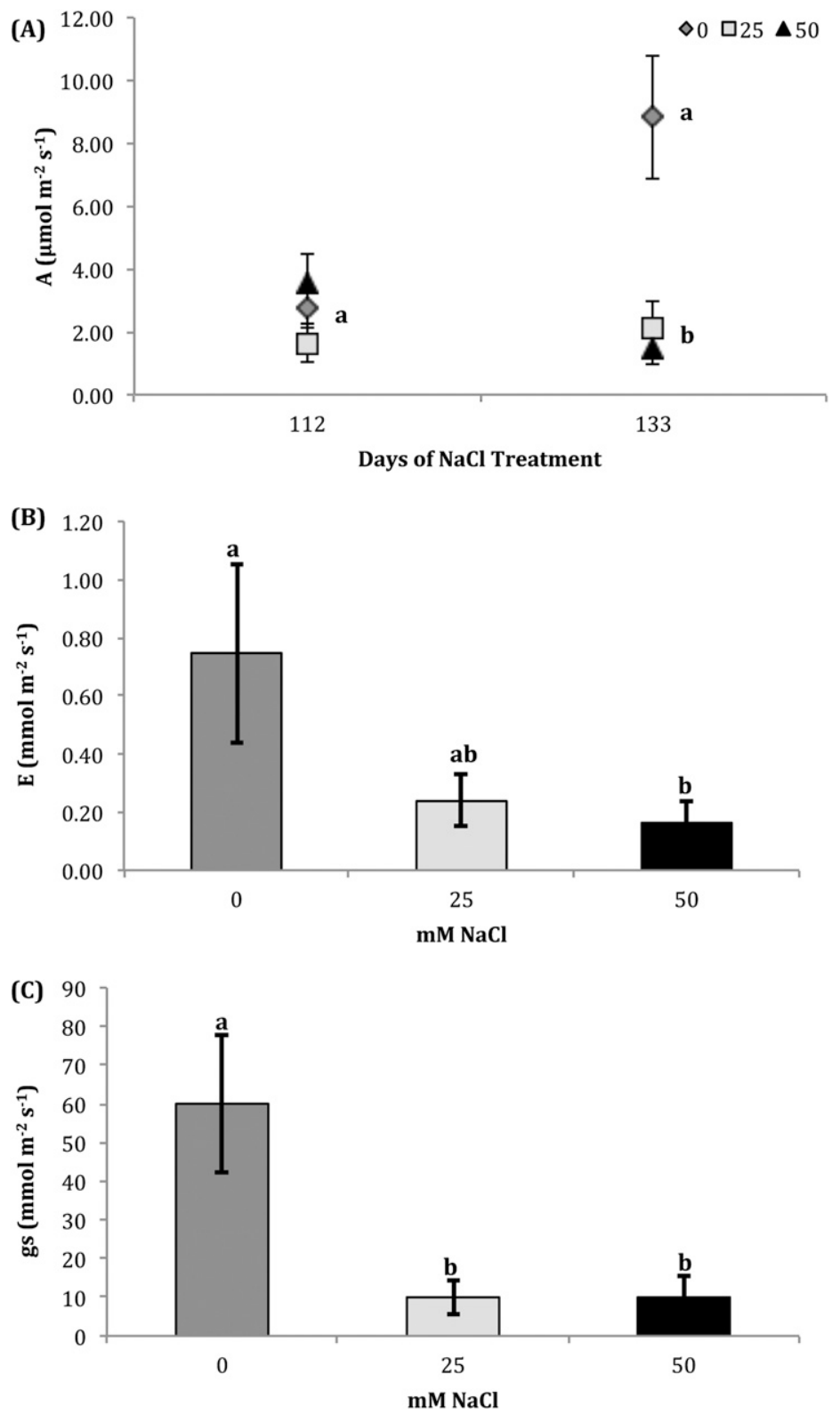

Fig. 2. Mean $\pm \operatorname{SE}(\mathbf{A})$ carbon assimilation rate (A), (B) transpiration rate (E), and (C) stomatal conductance $\left(g_{\mathrm{S}}\right)$ of two daffodil cultivars ('Dutch Master' and 'Tete-a-Tete') exposed to saline irrigation $(0,25$, or $50 \mathrm{~mm} \mathrm{NaCl}$ ) for $98 \mathrm{~d}$ preemergence and $35 \mathrm{~d}$ postemergence. Transpiration and $g_{\mathrm{S}}$ values are reported for Day 133. As there were no cultivar differences the means within a salinity treatment are from all cultivars combined. Salinity treatments with the same lower case letter on the same day are not significantly different according to Tukey's honestly significant difference $(P<0.05)$. Data are means of one run of three replications of each cultivar in each salinity ( $n=6$ for each salinity).

significantly affected by salinity or cultivar and was an average of $-1.09 \pm 0.03 \mathrm{MPa}$.

Shoot $\mathrm{Ca}^{2+}$ and $\mathrm{Mg}^{2+}$ contents were not significantly affected by salinity with a mean percent dry weight \pm SE of $0.38 \% \pm 0.03 \%$ dry weight and $0.24 \% \pm 0.03 \%$ dry weight for $\mathrm{Ca}^{2+}$ and $\mathrm{Mg}^{2+}$, respectively. Shoot $\mathrm{K}^{+}$and $\mathrm{Na}^{+}$were both affected by salinity. The shoot $\mathrm{K}^{+}$concentration was significantly decreased in both the 25 and $50 \mathrm{~mm} \mathrm{NaCl}$ treatments compared with the $0 \mathrm{~mm} \mathrm{NaCl}$ control, but only in 'Tete-a-Tete' and 'Dutch Master' (Table 2). Sodium concentration significantly increased with increasing salinity with 'Dutch Master' maintaining the lowest $\mathrm{Na}^{+}$concentration and 'Actaea' the highest (Table 2).
In the bulbs, $\mathrm{Ca}^{2+}$ and $\mathrm{Mg}^{2+}$ contents were also unaffected by salinity with a mean percent dry weight \pm SE of $0.30 \% \pm 0.03 \%$ and $0.10 \% \pm$ $0.00 \%$ for $\mathrm{Ca}^{2+}$ and $\mathrm{Mg}^{2+}$, respectively. Bulb $\mathrm{K}^{+}$and $\mathrm{Na}^{+}$were both affected by salinity with variation in salinity response among cultivars. $\mathrm{K}^{+}$concentration was significantly increased in the $50 \mathrm{~mm} \mathrm{NaCl}$ treatment in both 'Ice Follies' and 'Actaea' (Table 2). $\mathrm{Na}^{+}$concentration was significantly affected by salinity with the $\mathrm{Na}^{+}$concentration in the $50 \mathrm{~mm}$ $\mathrm{NaCl}$ treatment being significantly greater than the control for all cultivars but 'Ice Follies' (Table 2). The ratio of $\mathrm{Na}^{+}$in the shoot compared with the bulb varied significantly by salinity and cultivar with reductions in both the 25 and $50 \mathrm{~mm} \mathrm{NaCl}$ treatments in 'Dutch Master' but no significant reductions resulting from salinity in any of the other three cultivars (Table 2). The shoot $\mathrm{K}^{+}: \mathrm{Na}^{+}$ratio was significantly affected by salinity with the lowest ratio in the highest salinity treatment (Table 2). A similar trend was observed in the bulb $\mathrm{K}^{+}: \mathrm{Na}^{+}$ratio for 'Tete-a-Tete' and 'Dutch Master'; however, in the bulbs, the 25 and $50 \mathrm{~mm}$ $\mathrm{NaCl}$ treatments did not differ significantly from each other (Table 2).

Plant growth, carbon assimilation, and plant ion status when moderate salinity treatment began postemergence. Growth rate was unaffected by salinity but did vary significantly by cultivar with 'Tete-a-Tete' having the highest growth rate and 'Ice Follies' and 'Dutch Master' having the lowest growth rate (Fig. 3A). Shoot fresh weight and dry weight were significantly correlated $\left(R^{2}=0.88, P<0.0001\right)$; therefore, only the data for shoot dry weight are presented. Shoot dry weight was significantly affected by salinity and cultivar but with no significant interaction (Fig. 3B). 'Tete-a-Tete' accumulated the most shoot biomass, whereas 'Actaea' accumulated the least. Shoot dry weight was only significantly reduced in the $50 \mathrm{~mm} \mathrm{NaCl}$ treatment (Fig. 3B). The change in bulb fresh weight from the beginning to the end of the experiment was significantly affected by salinity and cultivar (Fig. 3C). The bulbs in the $0 \mathrm{~mm} \mathrm{NaCl}$ control had the greatest change, whereas those in the two salinity treatments were significantly reduced (Fig. 3C). 'Tete-a-Tete' had the greatest increase in bulb fresh weight, whereas 'Dutch Master' had the least (Fig. 3C). Bulb dry weight was significantly reduced in the $50 \mathrm{~mm} \mathrm{NaCl}$ treatment with 'Actaea' having the greatest bulb dry weight and 'Dutch Master' the least (when initial bulb weight is taken into account) (Fig. 3D). The dry weight shoot-to-bulb ratio was significantly affected by salinity with reductions of $14 \%$ and $30 \%$ compared with the control in the 25 and $50 \mathrm{~mm} \mathrm{NaCl}$ treatments, respectively (Table 3). The number of flowers produced per plant was not significantly affected by salinity, although it did vary significantly among cultivars. The average number of flowers per cultivar \pm SE was for 'Tete-aTete' $7.73 \pm 1.12$, for 'Dutch Master' $1.43 \pm$ 0.36 , for 'Ice Follies' $1.17 \pm 0.17$, and for 'Actaea' $0 \pm 0.00$. Flowering times were also affected by cultivar, but not by salinity. 'Tete-a-Tete' flowered most quickly with an average time \pm SE of $1.53 \pm 0.09$ weeks followed by 'Dutch Master' $(2.61 \pm 0.15$ weeks) and 'Ice Follies' ( $2.63 \pm 0.15$ weeks $)$. 'Actaea' did not flower during the experimental period.

Carbon assimilation was measured after 14,21 , and $28 \mathrm{~d}$ of $\mathrm{NaCl}$ treatment. At $14 \mathrm{~d}$, the $P A R$ was only $200 \mu \mathrm{mol} \cdot \mathrm{m}^{-2} \cdot \mathrm{s}^{-1}$ and all treatments had similar low assimilation rates (Fig. 4A). At 21 and $28 \mathrm{~d}$ of $\mathrm{NaCl}$ treatment, the $P A R$ was on average $400 \cdot \mu \mathrm{mol} \cdot \mathrm{m}^{-2} \cdot \mathrm{s}^{-1}$, but there were no significant differences in carbon assimilation rate among treatments until $28 \mathrm{~d}$ of $\mathrm{NaCl}$ treatment. At $28 \mathrm{~d}$ of 

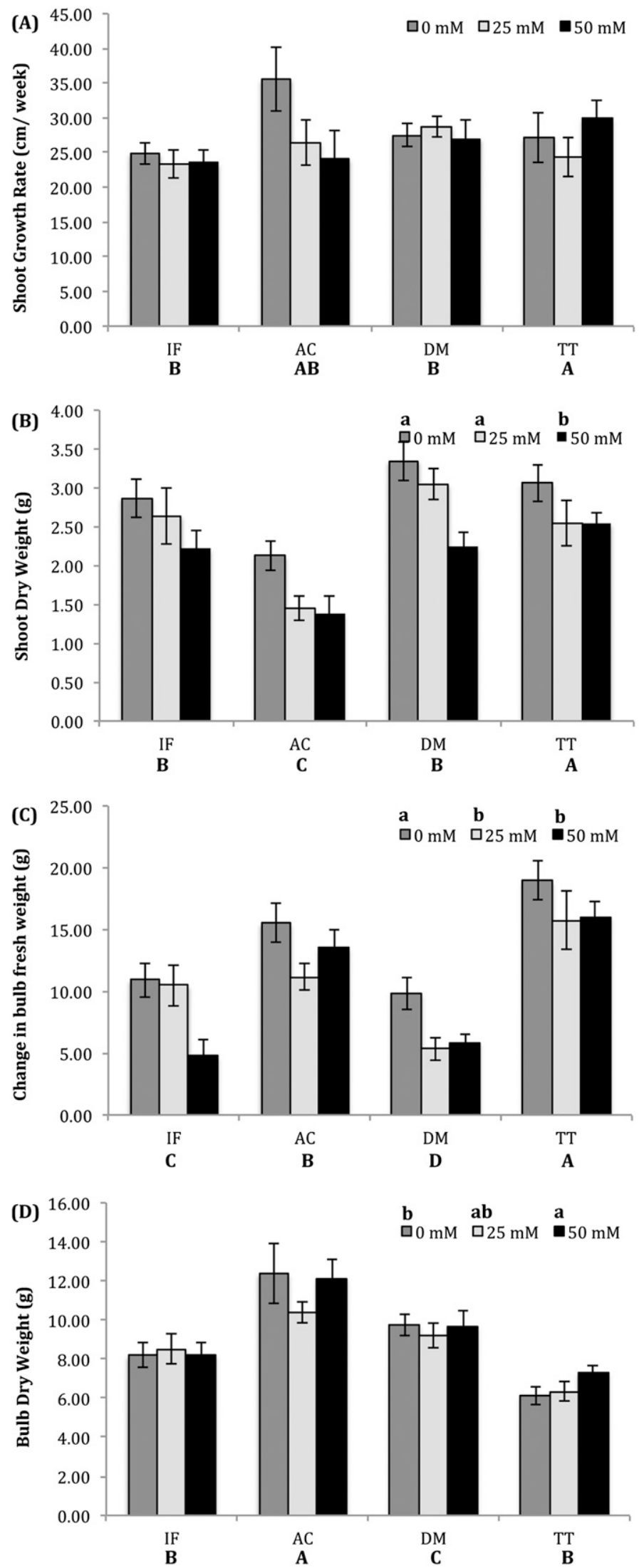

Fig. 3. Mean \pm SE shoot (A) growth rate, (B) fresh weight, (C) dry weight, and mean \pm SE bulb (D) change in fresh weight and $(\mathrm{E})$ dry weight of four daffodil cultivars exposed to saline irrigation $(0,25$, or $50 \mathrm{~mm}$ $\mathrm{NaCl}$ ) for $35 \mathrm{~d}$ postemergence. Cultivar abbreviations are as follows: 'Ice Follies' (IF), 'Actaea' (AC), 'Dutch Master' (DM), and 'Tete-a-Tete' (TT). Cultivars with the same capital letter are not significantly different according to Tukey's honestly significant difference (HSD) $(P<0.05)$ and salinity treatments with the same lower case letter are not significantly different according to Tukey's HSD $(P<0.05)$. Data are means of two runs of five replications of each cultivar in each salinity treatment $(\mathrm{n}=10)$. treatment, the carbon assimilation rate in the $50 \mathrm{~mm} \mathrm{NaCl}$ treatment was only $32 \%$, the assimilation rate of the $0 \mathrm{~mm} \mathrm{NaCl}$ control (Fig. 4A). At $28 \mathrm{~d}$ of $\mathrm{NaCl}$ treatment, there was a significant reduction in the transpiration rate $(\mathrm{E})$ in the $50 \mathrm{~mm} \mathrm{NaCl}$ treatment compared with the other two treatments (Fig. 4B). There did appear to be a reduction in $g_{\mathrm{S}}$ in the $50 \mathrm{~mm} \mathrm{NaCl}$ treatment as well (Fig. 4C), but this was not significantly different possibly as a result of the low number of measurements. Leaf RWC did not vary among salinity treatments or cultivars and was an average of $73 \% \pm 1 \%$. Leaf $\psi_{\mathrm{S}}$ was also unaffected by salinity or cultivar with an average $\psi_{\mathrm{S}}$ of $-1.07 \pm 0.02 \mathrm{MPa}$.

Shoot $\mathrm{Ca}^{2+}, \mathrm{Mg}^{2+}$, and $\mathrm{K}^{+}$were only significantly affected by cultivar with 'Tete-aTete' consistently having the highest concentrations of cations and 'Dutch Master' the lowest (Table 3). Shoot $\mathrm{Ca}^{2+}$ and $\mathrm{Mg}^{2+}$ were a mean percent dry weight \pm SE of $0.54 \% \pm$ $0.02 \%$ and $0.19 \% \pm 0.01 \%$ dry weight, respectively. Shoot $\mathrm{Na}^{+}$content was significantly affected by both salinity and cultivar with a significant salinity $\times$ cultivar interaction. Shoot $\mathrm{Na}^{+}$content was significantly greater in 'Tete-a-Tete' plants exposed to 25 and $50 \mathrm{~mm} \mathrm{NaCl}$ treatments compared with the $0 \mathrm{~mm} \mathrm{NaCl}$ control (Table 3 ). There was also a small, but significant, increase in shoot $\mathrm{Na}^{+}$concentration in the $50 \mathrm{~mm} \mathrm{NaCl}$ treatment of 'Actaea' (Table 3).

Bulb $\mathrm{Ca}^{2+}$ and $\mathrm{Mg}^{2+}$ were significantly different among cultivars with 'Actaea' consistently having the lowest concentrations of these two ions with an overall mean percent dry weight \pm SE of all cultivars of $0.23 \% \pm$ $0.02 \%$ and $0.09 \% \pm 0.00 \%$ dry weight for $\mathrm{Ca}^{2+}$ and $\mathrm{Mg}^{2+}$, respectively. Bulb $\mathrm{Na}^{+}$concentrations were significantly increased in the 25 and $50 \mathrm{~mm} \mathrm{NaCl}$ treatments compared with the $0 \mathrm{~mm} \mathrm{NaCl}$ control (Table 3), except in 'Dutch Master', in which the highest $\mathrm{Na}^{+}$ content was in the $25 \mathrm{~mm} \mathrm{NaCl}$ treatment (Table 3). The relative concentrations of $\mathrm{Na}^{+}$ in the shoot and the bulb did not differ significantly among salinity treatments; however, we did observe a significant salinity $\times$ cultivar interaction in which the $\mathrm{Na}^{+}$content in the $50 \mathrm{~mm} \mathrm{NaCl}$ treatment was significantly increased in the shoots of 'Tete-a-Tete' and significantly reduced in the shoots of 'Ice Follies' (Table 3 ) compared with the $0 \mathrm{~mm}$ $\mathrm{NaCl}$ control. Although there were no significant changes in $\mathrm{K}^{+}$content related to salinity, both the shoot and bulb $\mathrm{K}^{+}: \mathrm{Na}^{+}$ratios were significantly decreased in the 25 and $50 \mathrm{~mm}$ $\mathrm{NaCl}$ treatments compared with the $0 \mathrm{~mm}$ $\mathrm{NaCl}$ control for most cultivars (Table 3 ).

\section{Discussion}

Like with all ornamental plant production, to maximize profits, daffodil growers need to produce as many daffodils as possible at minimal cost for inputs (Hanks, 2002; Krug et al., 2006; Sage et al., 2000). Using lowquality water that is either brackish or saline could reduce water costs to growers (Arabiyat, 2005; Carter et al., 2005; Kirzhner et al., 2008; 
Table 3. Ratios of shoot to bulb biomass, shoot and bulb $\mathrm{K}^{+}$and $\mathrm{Na}^{+}$content $(\% \mathrm{DW})$, and $\mathrm{K}^{+}: \mathrm{Na}^{+}$ratio in four daffodil cultivars exposed to saline irrigation $(0,25$, or $50 \mathrm{~mm} \mathrm{NaCl})$ for $35 \mathrm{~d}$ postemergence. ${ }^{\mathrm{z}}$

\begin{tabular}{|c|c|c|c|c|c|c|c|}
\hline & \multirow[b]{2}{*}{ Shoot:bulb } & \multicolumn{3}{|c|}{ Shoot } & \multicolumn{3}{|c|}{ Bulb } \\
\hline & & $\mathrm{K}^{+}$ & $\mathrm{Na}^{+}$ & $\mathrm{K}^{+}: \mathrm{Na}^{+}$ & $\mathrm{K}^{+}$ & $\mathrm{Na}^{+}$ & $\overline{\mathrm{K}^{+}: \mathrm{Na}^{+}}$ \\
\hline \multicolumn{8}{|c|}{ Ice Follies } \\
\hline 0 & $0.38 \mathrm{a}^{\mathrm{y}}$ & 3.14 & $0.78 \mathrm{a}$ & $42.64 \mathrm{a}$ & 0.78 & $0.77 \mathrm{~b}$ & $3.72 \mathrm{a}$ \\
\hline 25 & $0.34 \mathrm{ab}$ & 3.27 & $0.89 \mathrm{a}$ & $17.58 \mathrm{~b}$ & 0.88 & $0.89 \mathrm{a}$ & $2.15 \mathrm{a}$ \\
\hline 50 & $0.28 \mathrm{~b}$ & 3.10 & $0.70 \mathrm{a}$ & $30.68 \mathrm{ab}$ & 1.02 & $0.96 \mathrm{a}$ & $1.57 \mathrm{a}$ \\
\hline \multicolumn{8}{|c|}{ Actaea } \\
\hline 0 & $0.19 \mathrm{a}$ & 2.64 & $0.76 \mathrm{~b}$ & $28.58 \mathrm{a}$ & 0.73 & $0.76 \mathrm{~b}$ & $6.73 \mathrm{a}$ \\
\hline 25 & $0.14 \mathrm{a}$ & 2.65 & $0.96 \mathrm{ab}$ & $6.23 \mathrm{~b}$ & 0.73 & $0.90 \mathrm{a}$ & $2.13 \mathrm{~b}$ \\
\hline 50 & $0.11 \mathrm{a}$ & 2.74 & $1.08 \mathrm{a}$ & $10.27 \mathrm{~b}$ & 0.78 & $0.91 \mathrm{a}$ & $1.74 \mathrm{~b}$ \\
\hline \multicolumn{8}{|c|}{ Dutch Master } \\
\hline 0 & $0.35 \mathrm{a}$ & 3.01 & $0.74 \mathrm{a}$ & $67.74 \mathrm{a}$ & 0.88 & $0.77 \mathrm{~b}$ & $5.93 \mathrm{a}$ \\
\hline 25 & $0.34 \mathrm{a}$ & 2.85 & $0.79 \mathrm{a}$ & $33.47 \mathrm{ab}$ & 0.86 & $0.92 \mathrm{a}$ & $2.12 \mathrm{~b}$ \\
\hline 50 & $0.24 \mathrm{~b}$ & 2.66 & $0.82 \mathrm{a}$ & $12.69 \mathrm{~b}$ & 0.76 & $0.77 \mathrm{~b}$ & $4.00 \mathrm{~b}$ \\
\hline \multicolumn{8}{|c|}{ Tete-a-Tete } \\
\hline 0 & $0.52 \mathrm{a}$ & 3.88 & $0.76 \mathrm{~b}$ & $35.66 \mathrm{a}$ & 1.14 & $0.75 \mathrm{~b}$ & $7.13 \mathrm{a}$ \\
\hline 25 & $0.41 \mathrm{~b}$ & 3.91 & $1.25 \mathrm{a}$ & $9.32 \mathrm{~b}$ & 1.09 & $1.01 \mathrm{a}$ & $1.78 \mathrm{~b}$ \\
\hline 50 & $0.35 \mathrm{~b}$ & 3.67 & $1.79 \mathrm{a}$ & $4.12 \mathrm{c}$ & 0.95 & $0.98 \mathrm{a}$ & $1.30 \mathrm{~b}$ \\
\hline
\end{tabular}

${ }^{z}$ Data are means of two runs of five replications of each cultivar in each salinity treatment $(\mathrm{n}=10)$.

yalues within the same column within the same cultivar with the same letter were not significantly different according to Tukey's honestly significant difference at $P \leq 0.05$.

$\mathrm{DW}=$ dry weight.

Marcum, 2006; Shillo et al., 2002). Daffodils are one of the most important flowering bulbs with thousands of cultivars (Benschop et al., 2010; Hanks, 2002; Meerow, 2012). 'Ice Follies' (Division II), 'Tete-a-Tete' (Division XII), and 'Dutch Master' (Division I) are three of the most popular cultivars (Hanks, 2002) with 'Tete-a-Tete' resulting in more sales than any other daffodil cultivar (The American Daffodil Society, 2006). Our goal was to evaluate how these three cultivars and one mid-/late-season cultivar, Actaea (Division IX), respond to moderate salinities when salinity exposure began either pre- or postemergence.

'Dutch Master' appeared to have the highest growth and bulb dry weight (Figs. $1 \mathrm{~A}$ and $1 \mathrm{E}$ and $3 \mathrm{~A}$ and $3 \mathrm{D}$ ), but its initial bulb weight was so much greater than that of the other cultivars that it negated any advantage it appeared to have over the other cultivars resulting in 'Tete-a-Tete' being significantly higher for most response variables measured. 'Dutch Master', 'Ice Follies', and 'Tete-a-Tete' grew well and had timely flower production regardless of when salinity exposure began. This negligible visual response to salinity even when applied preemergence may be the result of these being early-season cultivars so that flowering occurs very quickly once the induction period is over. On the other hand 'Actaea', which is a mid-/late-season cultivar, is exposed to salinity for so much longer during active growth, which could account for the much stronger effect that salinity had on the growth, visual quality, and flowering time of this cultivar compared with the other cultivars, particularly when salinity treatment began preemergence (Figs. $1 \mathrm{~A}$ and $1 \mathrm{~F}$ ).

Although shoot dry biomass was decreased by exposure to salinity, and the shoot-to-bulb ratio decreased as salinity increased, there was no significant effect of salinity on shoot growth, leaf number, and flower production in the postemergence experiment and salinity negatively affected these traits only in
'Actaea' in the preemergence experiment (Fig. 1). There were no significant changes in RWC or $\psi_{\mathrm{S}}$ observed that could account for this disparity (i.e., growth being maintained by increasing turgor).

In 'Star Gazer' lilies, the first month of plant growth is fueled by the bulb until a sufficient number of leaves has been formed to support the plant through photosynthesis (Chang and Miller, 2003). A similar process may be occurring in daffodils. In our experiments, the plants in all of the treatments had low carbon assimilation rates within in the first 2 to 3 weeks of growth within the greenhouse, but by $28 \mathrm{~d}$, carbon assimilation rate was increased in the $0 \mathrm{~mm} \mathrm{NaCl}$ control but not the $50 \mathrm{~mm} \mathrm{NaCl}$ treatment or the 25 and $50 \mathrm{~mm} \mathrm{NaCl}$ treatments in the postemergence and preemergence experiments, respectively (Figs. 2 and 4). As salinity built up in the root zone (Table 1), $g_{\mathrm{S}}$ and transpiration rates declined with a consequent reduction in net photosynthesis (Figs. 2 and 4). Therefore, the bulbs exposed to higher salinity may have had to fuel shoot growth longer, resulting in less change in the bulb fresh weight, yet the final bulb dry weight was not significantly affected by salinity, but shoot dry weight was, indicating that at the reduced levels of photosynthesis experienced in the salinity treatments, biomass resources were concentrated into the bulb rather than the shoots, resulting in a decreased shoot-to-root ratio at increased salinity (Tables 2 and 3). Fueling resources into the bulb after anthesis is common to all daffodils, ensuring the ability of the plant to produce the next year (Hanks, 2002). Only 'Actaea' in the preemergence experiment showed any reductions in shoot growth in response to salinity (Fig. 1A). 'Actaea' had a longer exposure to $\mathrm{Na}^{+}$than the other three cultivars and consequently a greater buildup of $\mathrm{Na}^{+}$within the leaves (Table 2) so that 'Actaea' may have been exposed to toxic effects of $\mathrm{Na}^{+}$that would directly impact shoot growth that were not encountered in the three early-season cultivars.
In the postemergence experiment, both 'Actaea' and 'Tete-a-Tete' had significantly increased $\mathrm{Na}^{+}$concentration within the shoots at elevated salinities. On the other hand, 'Ice Follies' and 'Dutch Master' did not have increased $\mathrm{Na}^{+}$content within the shoots at higher salinities but did accumulate $\mathrm{Na}^{+}$ within the bulb (Table 3). These differences in shoot $\mathrm{Na}^{+}$accumulation resulted in very different $\mathrm{Na}^{+}$shoot-to-root ratios among cultivars (Table 3 ). The differences may be related to initial bulb size, which was larger in 'Dutch Master' and 'Ice Follies' or the different cultivars may have different mechanisms for dealing with salinity imposed by $\mathrm{NaCl}$. 'Tete-a-Tete' and 'Actaea' may have increased shoot $\mathrm{Na}^{+}$because of their increased growth rate (Fig. 3A) or may have a detoxification mechanism that allows for some $\mathrm{Na}^{+}$buildup in the shoots without drastic effects. On the other hand, 'Ice Follies' and 'Dutch Master' may attempt to sequester $\mathrm{Na}^{+}$ within the bulbs to protect the shoots from the adverse effects of $\mathrm{Na}^{+}$. 'Ice Follies' seemed to be particularly good at this when salinity exposure was short term like in the postemergence experiment with a $\mathrm{Na}^{+}$shoot-tobulb ratio of 0.51 in the $50 \mathrm{~mm} \mathrm{NaCl}$ treatment compared with a ratio of 0.91 in the $0 \mathrm{~mm}$ $\mathrm{NaCl}$ control. 'Dutch Master' showed a similar response but with the most dramatic effect seen in the preemergence experiment (Tables 2 and 3 ).

Because $\mathrm{Na}^{+}$did not have as large of an effect on shoot growth, we anticipated we hypothesize that the effects of $\mathrm{Na}^{+}$might be counteracted by the high $\mathrm{K}^{+}$concentration that is maintained within the shoot (Table 3 ). Potassium concentration in all cultivars was not significantly affected by salinity in the postemergence experiment (Table 3). Although there was a significant drop in $\mathrm{K}^{+}$ content in 'Dutch Master' and 'Tete-a-Tete' when salinity was applied preemergence (18\% and $29 \%$ decrease, respectively), there was no effect of salinity on $\mathrm{K}^{+}$content in 'Ice Follies' and 'Actaea', which additionally had significant increases in $\mathrm{K}^{+}$content in the bulb of $21 \%$ and $36 \%$, respectively (Table 2 ). Potassium has an important role in cellular function and is important in many plants for salt tolerance (Shirazi et al., 2005; Zhu, 2007). Maintaining a high $\mathrm{K}^{+}: \mathrm{Na}^{+}$ratio is linked to salinity tolerance (Chinnusamy et al., 2005; Kant and Kafkafi, 2002). Salinity significantly reduced the shoot $\mathrm{K}^{+}: \mathrm{Na}^{+}$ratio for all cultivars with a more drastic effect in the preemergence experiment for all cultivars but 'Dutch Master' (Tables 2 and 3). Although there were reductions in the $\mathrm{K}^{+}: \mathrm{Na}^{+}$ratio, perhaps the ratio was maintained at a high enough level to allow the daffodils to maintain good growth and visual quality.

Our results indicate that three of the most popular daffodil cultivars ('Tete-a-Tete', 'Dutch Master', and 'Ice Follies') can be exposed to saline irrigation with an EC at least $6.0 \mathrm{dS} \cdot \mathrm{m}^{-1}$ with root zone buildup at least twice that (Table 1) without a significant effect on visual quality and flower production. However, this may only apply to early-season 

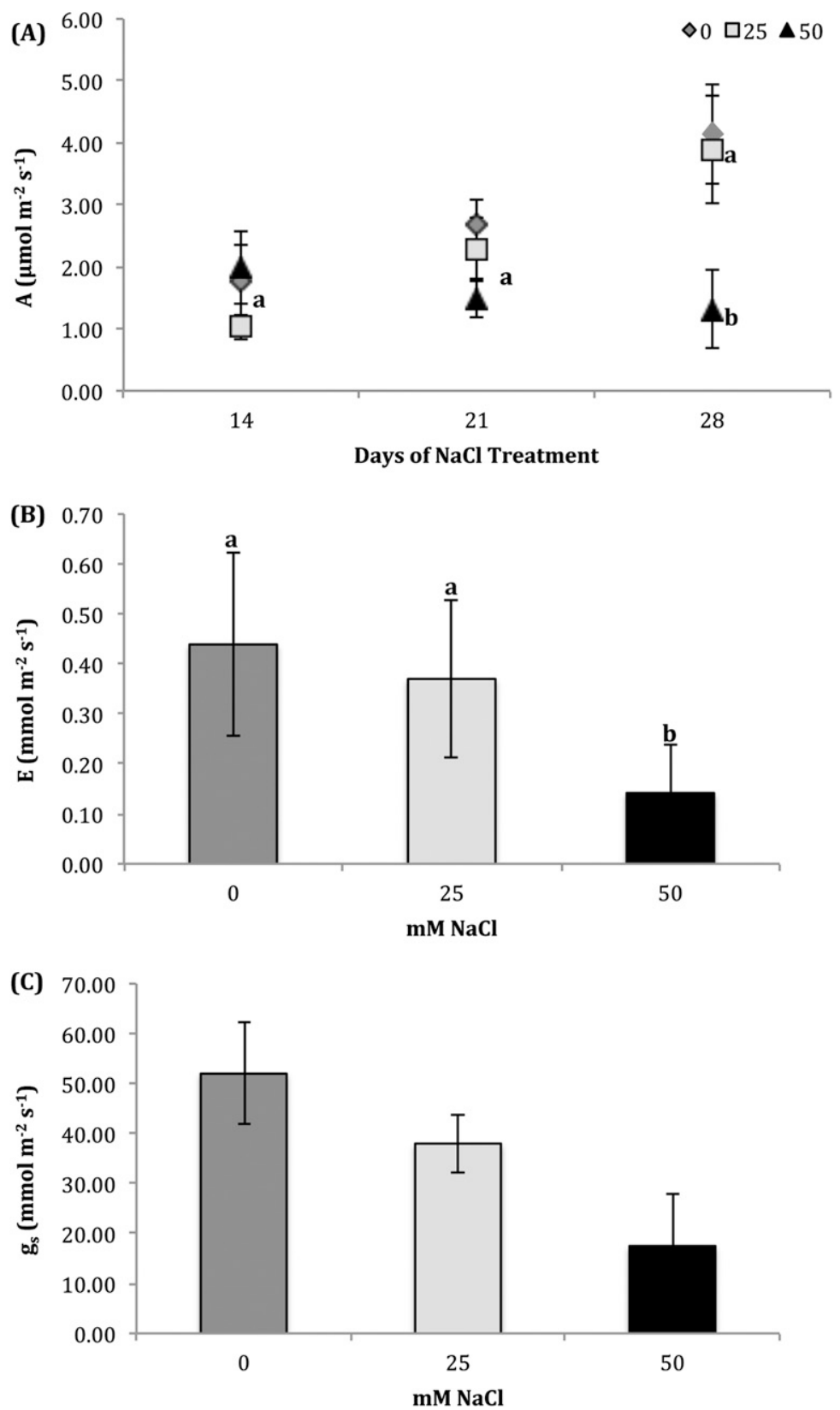

Fig. 4. Mean $\pm \mathrm{SE}(\mathbf{A})$ carbon assimilation rate (A), (B) transpiration rate (E), and (C) stomatal conductance $\left(g_{\mathrm{S}}\right)$ of four daffodil cultivars ('Actaea', 'Dutch Master', 'Ice Follies', and 'Tete-a-Tete' exposed to saline irrigation $(0,25$, or $50 \mathrm{~mm} \mathrm{NaCl})$ for $35 \mathrm{~d}$ postemergence. Because there were no cultivar differences, the means within a salinity treatment are from all cultivars combined. Salinity treatments with the same lower case letter on the same day are not significantly different according to Tukey's honestly significant difference $(P<0.05)$. Data are means of one run of three replications of each cultivar in each salinity ( $\mathrm{n}=12$ for each salinity).

cultivars that flower quickly, because salinity significantly impacted plant quality of 'Actaea' as the exposure period increased. We did not examine how salinity affects daffodil bulb quality and its ability to produce the next season; therefore, it may be the best practice to intersperse saline irrigation with irrigation from a high-quality source or to increase the leaching fraction to reduce salinity buildup in the root zone. Even some use of lower quality water could reduce costs to growers, because lower quality water is typically less expensive and more accessible than high-quality water (Arabiyat, 2005; Grattan, 2002; Marcum, 2006; Shillo et al., 2002).

\section{Literature Cited}

Anderson, N.R. and G. van der Hoeven. 1998 Forcing Bulbs. Kansas State Univ. Agric. Expt. Stat. Coop. Ext. Service MF-2077.

Arabiyat, S. 2005. Water price policies and incentives to reduce irrigation water demand: Jordan case study. Options méditerranéennes, Series B 52:137-151.

Auge, R.M., A.J.W. Stodola, J.L. Moore, W.E. Klingeman, and X. Duan. 2003. Comparative dehydration tolerance of foliage of several ornamental crops. Sci. Hort. 98:511-516.

Benschop, M., M. le Nard, H. Okubo, and A. de Hertogh. 2010. The global flower bulb industry: Production, utilization, research. Hort. Rev. 36:1-115.
Berkheimer, S.F. and E. Hanson. 2006. Deicing salts reduce cold hardiness and increase flower bud mortality of highbush blueberry. J. Amer. Soc. Hort. Sci. 131:11-16.

Bogeat-Triboulot, M.B., M. Brosche, J. Renaut, L. Jouve, D. Le Thiec, P. Fayyaz, B. Vinocur, E. Witters, K. Laukens, T. Teichmann, A. Altman, J.F. Hausman, A. Polle, J. Kangasjarvi, and E. Dreyer. 2007. Gradual soil water depletion results in reversible changes of gene expression, protein profiles, ecophysiology, and growth performance in Populus euphratica, a poplar growing in arid regions. Plant Physiol. 143:876-892.

Cantor, M. and C. Gheorghita. 2011. Technological solutions and indoor use of forcing bulb plants. Agricultura-Stiință şi practică 1-2:70-74.

Carder, J.H. and C.L. Grant. 2002. Breeding for resistance to basal rot in Narcissus. Acta Hort. 570:255-262.

Carter, C.T., C.M. Grieve, J.A. Poss, and D.L. Suarez. 2005. Production and ion uptake of Celosia argentea irrigated with saline wastewaters. Sci. Hort. 106:381-394.

Cassaniti, C., C. Leonardi, and T.J. Flowers. 2009. The effects of sodium chloride on ornamental shrubs. Sci. Hort. 122:586-593.

Chang, Y.C. and W.B. Miller. 2003. Growth and calcium partitioning in Lilium 'Star Gazer' in relation to leaf calcium deficiency. J. Amer. Soc. Hort. Sci. 128:788-796.

Chinnusamy, V., A. Jagendorf, and J.K. Zhu. 2005. Understanding and improving salt tolerance in plants. Crop Sci. 45:437-448.

Cunningham, M.A., E. Snyder, D. Yonkin, M. Ross, and T. Elsen. 2008. Accumulation of deicing salts in soils in an urban environment. Urban Ecosyst. 11:17-31

Daffodil.org. 1995-2011. Northern California Daffodil Society, Inc. Livermore, CA.

Ellis, F.L.S. 2002. Naming daffodils. BSBI News 89:26-31.

ERS. 1995. Field-grown bulb crops: An economic assessment of the feasibility of providing multiple-peril crop insurance. Bulbs, corms, tubers, rhizomes. USDA Report for the Federal Crop Insurance Corporation. Pp. 15. U.S. Dept. Agr., Washington, D.C

Francois, L.E. and R.A. Clark. 1978. Salt tolerance of ornamental shrubs, trees and iceplant. J. Amer. Soc. Hort. Sci. 107:66-68.

Grattan, S.R. 2002. Irrigation water salinity and crop production. University of California Division of Agriculture and Natural Resources, Davis, CA. Publication 8066.

Green, S.M., R. Machin, and M.S. Cresser. 2008. Effect of long-term changes in soil chemistry induced by road salt applications on $\mathrm{N}$-transformations in roadside soils. Environ. Pollut. 152:20-31.

Grusak, M.A. 1994. Iron transport to developing ovules of Pisum sativum. 1. Seed import characteristics and phloem iron-loading capacity of source regions. Plant Physiol. 104:649-655.

Gupta, S.D., R.M. Auge, P.D. Denchev, and B.V. Conger. 1995. Growth, proline accumulation and water relations of $\mathrm{NaCl}$-selected callus lines of Dactylis glomeratus L. Environ. Exp. Bot. 35:83-92.

Halperin, S.J., L.V. Kochian, and J.P. Lynch. 1997. Salinity stress inhibits calcium loading into the xylem of excised barley (Hordeum vulgare) roots. New Phytol. 135:419-427.

Hanks, G.R. 2002. Commercial production of Narcissus, p. 53-130. In: Hanks, G.R. (ed.). Narcissus and daffodil. The genus Narcissus. Taylor and Francis, London.

Hunter, D.A., A. Ferrante, P. Vernieri, and M.S Reid. 2004. Role of abscisic acid in perianth 
senescence of daffodil (Narcissus pseudonarcissus 'Dutch Master'). Physiol. Plant. 121: 313-321.

Hunter, D.A., B.C. Steele, and M.S. Reid. 2002. Identification of genes associated with perianth senescence in daffodil (Narcissus pseudonarcissus L. 'Dutch Master'). Plant Sci. 163:13-21.

Jones, R.B. and M. Hill. 1993. The effect of germicides on the longevity of cut flowers. J. Amer. Soc. Hort. Sci. 118:350-354.

Kant, S. and U. Kafkafi. 2002. Potassium and abiotic stresses in plants, p. 233-251. In: Pasricha, N.S. and S.K. Bansal (eds.). Role of potassium in nutrient management for sustainable crop production in India. Potash Research Institute of India, Gurgaon, Haryana.

Kirzhner, F., Y. Zimmels, and A. Gafhi. 2008. Effect of evapotranspiration on the salinity of wastewater treated by aquatic plants. Rev. Environ. Health 23:149-166.

Krug, B.A., B.E. Whipker, I. McCall, and J.M. Dole. 2006. Narcissus response to plant growth regulators. HortTechnology 16:129-132.

MAFF. 2012. Basic horticultural statistics for the United Kingdom. Calendar Years 1995-2011. MAFF Publications, London, UK.

Marcum, K.B. 2006. Use of saline and non-potable water in the turfgrass industry: Constraints and developments. Agr. Water Mgt. 80:132-146.

Meerow, A.W. 2012. Ornamental geophytes, p. 1756. In: Kamenetsky, R. and H. Okubo (eds.). Basic science to sustainable production. CRC Press, Boca Raton, FL.

Munns, R. and M. Tester. 2008. Mechanisms of salinity tolerance. Annu. Rev. Plant Physiol. 59:651-681.
Olsen, K.G. and L.J. Ulicny. 2001. Reduction of calcium concentrations by the Brita water filtration system: A practical experiment in titrimetry and atomic absorption spectroscopy. J. Chem. Educ. 78:941.

Parkin, J.P. 1992. Population dynamics of the wild daffodil (Narcissus pseudonarcissu). IV. Clumps and gaps. J. Ecol. 80:797-808.

Pomper, K.W. and M.A. Grusak. 2004. Calcium uptake and whole-plant water use influence pod calcium concentration in snap bean plants. J. Amer. Soc. Hort. Sci. 129:890-895.

Safi, M.I., A. Bulad, A. Blawenah, and I. Bashabsheh. 2007. Water use efficiency, flower yield and quality of 'Lilium aziatische' irrigated with different water types. Intl. J. Agr. Biol. 9:264266.

Sage, D.O., J. Lynn, and N. Hammatt. 2000. Somatic embryongenesis in Narcissus pseudonarcissus cvs. Golden Harvest and St. Keverne. Plant Sci. 150:209-216.

Santos-Gally, R., P. Vargas, and J. Arroyo. 2011 Insights into Neogene Mediterranean biogeography based on phylogenetic relationships of mountain and lowland lineages of Narcissus (Amaryllidaceae). J. Biogeogr. 39:782-798.

SAS Institute Inc. 1989-2008. Jump, Version 8 SAS Institute Inc., Cary, NC.

Shannon, M.C. and C.M. Grieve. 1999. Tolerance of vegetable crops to salinity. Sci. Hort 78:5-38.

Shibli, R.A., M. Kushad, G.G. Yousef, and M.A. Lila. 2007. Physiological and biochemical responses of tomato microshoots to induced salinity stress with associated ethylene accumulation. Plant Growth Regulat. 51:159-169.
Shillo, R., M. Ding, D. Pasternak, and M. Zaccai. 2002. Cultivation of cut flower and bulb species with saline irrigation. Sci. Hort. 92:41-54.

Shirazi, M.U., M.Y. Ashraf, M.A. Khan, and M.H. Naqvi. 2005. Potassium induced salinity tolerance in wheat (Triticum aestivum L.). Intl. J. Environ. Sci. Technol. 2:233-236.

Sonneveld, C., R. Baas, H.H.M. Rijssen, and J. de Hoog. 1999. Salt tolerance of flower crops grown in soilless culture. J. Plant Nutr. 22: 1033-1048

Steininger, J. 2010. The lowdown on daffodils. Greenhouse Grower March:52-55.

The American Daffodil Society. 2006. Miniature daffodils. 10 Sept. 2009. <http://www.daffodilusa. org/pdfs/Miniprog/Miniature_Daffodils_Script. pdf $>$.

Van Doorn, W.G. 1998. Effects of daffodil flowers on the water relations and vase life of roses and tulips. J. Amer. Soc. Hort. Sci. 123:146-149.

Van Doorn, W.G., A. Sinz, and M.M. Tomassen. 2004. Daffodil flowers delay senescence in cut Iris flowers. Phytochemistry 65:571-577.

Wahome, P.K., H.H. Jesch, and I. Grittner. 2000. Effect of $\mathrm{NaCl}$ on the vegetative growth and flower quality of roses. J. Appl. Bot. 74:38-41.

Wang, Y., S. Mopper, and K.H. Hasenstein. 2001. Effects of salinity on endogenous ABA, IAA, JA, and SA in Iris hexagona. J. Chem. Ecol. 27:327-342.

Zhu, J.K. 2007. Plant salt stress. Encycl. Life Sci. doi: 10.1002/9780470015902a001300.pub2.

Zollinger, N., R. Koenig, T. Cerny-Koenig, and R. Kjelgren. 2007. Relative salinity tolerance of intermountain western United States native herbaceous perennials. HortScience 42:529-534. 